DOI: https://doi.org/10.18371/fp.2(38).2020.209289

УДК 336:004

\title{
ФІНАНСОВА БЕЗПЕКА В УМОВАХ ЦИФРОВОЇ ЕКОНОМІКИ: ОЧІКУВАННЯ I РЕАЛЬНІСТЬ
}

\author{
ПАНТЄЛЄЄВА Наталія Миколаївна \\ доктор економічних наук, доцент \\ Черкаський інститут \\ ДВНЗ «Університет банківської справи» \\ ORCID ID: https://orcid.org/0000-0001-6457-6912 \\ e-mail:nnpanteleeva2017@gmail.com
}

\begin{abstract}
Анотація: $B$ cmaтmi проведено аналіз наукових поглядів на сутність і чинники фінансової безпеки. Розкрито характеристики ичифрових технологій $і$ фінансових інновацій на їх основі щзодо очікувань $і$ впливів на фiнансову безпеку. Визначено, щзо криптовалюта є радикальною фінансовою інновацією, зі зростанням капіталізацї ринку якої варто очікувати виникнення ризиків для монетарної політики, міжнародної валютної системи, міжнародних розрахунків і кредитування, залучення інвестицій тощчо. Охарактеризовано позицію цчентральних банків щзодо регулювання криптовалют та випуску ииифрової валюти центральних банків. Надано оиінку можливим наслідкам впливу поширення криптовалюти на бюджетну безпеку. Узагальнення практики оподаткування криптовалют, дозволило визначити загрози податкової безпеки та завдання їх нейтралізаuіiі. Обгрунтовано потениійні можливості цифрових технологій (Big Data, штучний інтелект, машинне навчання, блокчейн) $i$ фінансових інноващій на їх основі щуодо змічнення фінансової безпеки.
\end{abstract}

Ключові слова: фінансова безпека, фінансово-кредитна безпека, валютна безпека, бюджетна безпека, податкова безпека, ичифрова економіка, фінансові інноващії, ијифрові технологї, криптовалюта, Big Data, штучний інтелект, машинне навчання, блокчейн.
Аннотация: $B$ cmambе проведен анализ научных взглядов на сущность и факторы финансовой безопасности. Раскрыты характеристики иифровых технологий и финансовых инноваций на их основе относительно ожиданий и воздействия на финансовую безопасность. Определено, что криптовалюта является радикальной финансовой инновацией, с ростом капитализации рынка которой следует ожидать возникновения рисков для монетарной политики, международной валютной системы, международных расчетов и кредитования, привлечения инвестиций. Охарактеризовано позицию цеентральных банков по регулированию криптовалюты и выпуска цүифровой валюты иентральных банков. Дана оченка возможных последствий влияния распространения криптовалюты на бюджетную безопасность. Обобщение практики налогообложения криптовалюты позволило определить угрозы налоговой безопасности и мероприятия их нейтрализачии. Обосновано потенциальные возможности ииирровых технологий (Big Data, искусственный интеллект, машинное обучение, блокчейн) и финансовых инноваций на их основе по укреплению финансовой безопасности.

Ключевые слова: финансовая безопасность, финансово-кредитная безопасность, валютная безопасность, бюджетная безопасность, налоговая безопасность, иифровая экономика, финансовые инновачии, иифрровые технологии, криптовалюта, Big Data, искусственный интеллект, машинное обучение, блокчейн. 
Постановка проблеми. Еволюційний поступ цифрової економіки та прояви світових цифрових трендів все більше спостерігаються в зростанні ролі інформації, посиленні трансформації фінансової інфраструктури, збільшенні обсягів та прискоренні руху фінансових потоків, зростанні конкуренції та дезінтермедіації на ринку фінансових послуг. Багатоаспектність, суб' єктно-об' єктна, функціональна та технологічна різноманітність поширення процесів цифровізації привносять додаткову невизначеність впливу на всі складові фінансової безпеки. Все це зумовлює необхідність комплексного розв'язання наукової проблеми обгрунтування теоретикометодологічної парадигми фінансової безпеки відповідно в умовах цифрової економіки та розробки на цій основі відповідних механізмів оздоровлення фінансової системи, забезпечення фінансової стабільності та сталого економічного розвитку.

Аналіз останніх досліджень і публікацій. Теоретико-методоло-гічний базис досліджень забезпечення фінансової безпеки, структурних зрушень і перспектив цифрової економіки формують наукові праці зарубіжних і вітчизняних учених. Зокрема, проблемні аспекти забезпечення фінансової безпеки як структурної складової економічної безпеки держави та економічних агентів розглянуто в роботах О. Амосова, О. Ареф'єва, О. Барановського, І. Бланка, 3. Варналія, В. Геєця, А. Єпіфанова, М. Єрмошенко, С. Онищенко, П. Пашко та ін. 3 розвитком постіндустріального суспільства стало поглиблюватись теоретичне підгрунтя об' єктних основ, сут- нісних характеристик та категоріальних особливостей цифрової економіки в наукових публікаціях С. Веретюка, Е. Ведути, С. Коляденко, В. Ляшенко, Д. Тапскотта, К. Шваба, Б. Чакраворті та ін.. При цьому свого розвитку набуває новий напрям наукових досліджень проблемних питань регулювання процесів цифровізації, перспективи, ризиків і загроз впровадження цифрових технологій і поширення феномену FinTech, цифрової трансформації фінансового посередництва, про що свідчать публікації П. Винья [1], Н. Вовченок [2], П. Гомбера [3], С. Дароллес [4], Т. Дж. Макдональда [5], М. Малона [6], Г. Карчевої [7], В. Корнєєва [8], Н. Пантєлєєвої [9], П. Тревелева [10], А. Омарини [11] та ін. Незважаючи на значну увагу, питання взаємозв'язку та взаємозалежності цифрової економіка, цифрових технологій, фінансових інновацій на їх основі та фінансової безпеки поки ще не знайшли належного обгрунтування як 3 позиції теорії, так й практики. Все це визначило мету дослідження.

Мета статті полягає в аналізі наукових поглядів на сутність і чинники фінансової безпеки, розкритті особливостей та якісних характеристик фінансових інновацій на основі цифрових технологій щодо очікувань і впливів на фінансову безпеку в умовах цифрової економіки.

Виклад основного матеріалу. Фінансова безпека є достатньо складним і багатоаспектним типологічним видом економічної безпеки. Сутнісні ознаки фінансової безпеки відрізняються залежно від суб'єкту економічних відносин. Аналіз позицій дослідників показує, що їх відмінність поля- 
гає в уточненні цільового спрямування ється зі станом того або іншого результуючої дії забезпечення фінансової безпеки з різним ступенем деталізації, але найчастіше вона асоціюсуб' єкту та підкреслюється вплив зовнішніх i внутрішніх чинників, здатність протистояти їм (табл. 1).

Таблиця 1

Плюралізм точок зору на поняття «фінансова безпека»

\begin{tabular}{|c|c|}
\hline Дослідник & Тлумачення поняття «фінансова безпека» - це ... \\
\hline С. Клоков [13] & $\begin{array}{l}\text { стан фінансових відносин, коли створюються прийнятні умови і необ- } \\
\text { хідні ресурси для розширеного відтворення, економічного зростання і } \\
\text { зростання добробугу населення, стабільності, збереження цілісності та } \\
\text { єдності фінансової системи держави для успішного протистояння внут- } \\
\text { рішнім і зовнішн ім факторам дестабілізації фінансового становища в } \\
\text { країні }\end{array}$ \\
\hline $\begin{array}{l}\text { М. Срмошен ко [14, } \\
\text { с. } 63]\end{array}$ & $\begin{array}{l}\text { ан фінансово-кредитної сфери держави, який характеризується зба- } \\
\text { нсованістю, стійкістю до внугрішніх і зовнішн іх негативних впливів, } \\
\text { атн істю ... забезпечувати ефективне функціонування національної } \\
\text { ономічної системи та економічне зростання. }\end{array}$ \\
\hline І. Бланк $[15$, с. 24$]$ & $\begin{array}{l}\text { кількісно і якісно детермінований рівень його (підприємства) фінансо- } \\
\text { вого стану, що забезпечує стабільну захищеність його пріоритетних, } \\
\text { збалансованих фінансових інтересів від ідентифікованих реальних і } \\
\text { потенційних загроз зовнішнього і внугрішнього характеру, параметри } \\
\text { якого визначаються на основі його фінансової філософії і створюють } \\
\text { необхідні передумови фінансової підтримки його стій кого зростання в } \\
\text { поточному і перспективному періоді }\end{array}$ \\
\hline Т. Болг & $\begin{array}{l}\text { стану банківських установ, що характеризується збалансованістю і } \\
\text { стійкістю до впливу зовнішніх і внугрішніх загроз, його здатністю до- } \\
\text { сягати поставлених цілей і генерувати достатній обсяг фінансових ре- } \\
\text { сурсів для забезпечення стійкого розвитку }\end{array}$ \\
\hline В. Вовк $[17$, с.202] & $\begin{array}{l}\text { стан банку (банківської системи в цілому), що характеризується здатн і- } \\
\text { стю протистояти можливим зовнішнім та внугрішн ім загрозам банків- } \\
\text { ської діяльності для забезпечення нормального фун кцінування та роз- } \\
\text { витку в умовах дестабілізуючого впливу оточуючого середовища та } \\
\text { захищеності фінансових інтересів зацікавлених сторін (власників, кліє- } \\
\text { нтів, працівників, керівництва, держави), а основною метою безпеки } \\
\text { банку є забезпечення кон курентоспроможності як окремого банку, так і } \\
\text { банківської системи в цілому на ринку банківських послуг та недоп у- } \\
\text { щення можливості отримання збитків або втрати частини прибутків } \\
\text { внаслідок реалізаціївнугрішніх та зовнішн іх загроз. }\end{array}$ \\
\hline
\end{tabular}

Джерело: сформовано автором на означеними посиланнями

Виходячи з комплексного підходу, O.I. Барановський вважає, що фінансова безпека - це: 1) важлива складова частина економічної безпеки...; 2) ступінь захищеності важливих фінансових інтересів...; 3) рівень забезпеченості фінансовими ресурсами ; 4) стан фінансової, грошовокредитної, валютної, бюджетної, по- даткової систем; 5) стан фінансових потоків в економіці; 6) якість фінансових інструментів, послуг і технологій; 7) цілеспрямований комплекс заходів фінансової, монетарної, валютної, антиінфляційної, податкової політик...[12, с.258-259]. Відповідно до цього постає питання забезпечення фінансової безпеки, дієвість системи 
якої залежить від ідентифікації їі чин-

ників (табл. 2).

Таблиця 2

Чинники фінансової безпеки, які зазнають вплив цифрової економіки

\begin{tabular}{|c|c|}
\hline Чинники & $\begin{array}{c}\text { Характеристика за окремими складовими } \\
\text { фінансової безпеки }\end{array}$ \\
\hline \multirow{4}{*}{ Економічні } & $\begin{array}{l}\text { фінансово-кредитна: фінансова стабільн ість, інфляція, джерела фінансу- } \\
\text { вання, інвестиційний клімат, іноземний капітал, податкове навантаження } \\
\text { суб'єктів господарювання та їх фінансова стійкість, рівень життя і довіра } \\
\text { населення, обсяги заощаджень, конкуренція, вартість кредитних ресурсів, } \\
\text { кредитна активність позичальників, кредитна заборгованість тощо; }\end{array}$ \\
\hline & $\begin{array}{l}\text { бюджетна: світовий фінансовий ринок, ринок капіталу, господарство; ве- } \\
\text { личина і збалансованість бюджету, бюджетні резерви, іноземні запозичен- } \\
\text { ня, інвестиційний клімат, структура експорту/імпорту, корупція, права вла- } \\
\text { сності на державні ресурси, стратегічно важливі підприємства тощо; }\end{array}$ \\
\hline & $\begin{array}{l}\text { податкова: тінізація та офшорізац ія економіки, корупція, фінансовий стан } \\
\text { суб'єктів господарювання та населення тощо; }\end{array}$ \\
\hline & $\begin{array}{l}\text { валютна: кризові явища на св ітовому валютному ринку, обсяг і склад ва- } \\
\text { лютних резерв ів, інфляція, режим курсоутворення і курс національної ва- } \\
\text { люти, відплив кап італу, доларизація і тіньова економіка, дестабілізація ле- } \\
\text { гального сектору тощо; }\end{array}$ \\
\hline \multirow{4}{*}{ Інституційні } & $\begin{array}{l}\text { фінансово-кредитна: національна фінансова та банківська системи, фінан- } \\
\text { совий і грошово-кредитний ринок, нормативно-правова база, грошово- } \\
\text { кредитна політика, незалежність та транспарентність центрального банку } \\
\text { тощо; }\end{array}$ \\
\hline & $\begin{array}{l}\text { бюджетна: національна бюджетна система, платіжно-розрахункова систе- } \\
\text { ма, нормативно-правова база, бюджетна політика тощо; }\end{array}$ \\
\hline & $\begin{array}{l}\text { nодаткова: національна податкова система, податкове законодавство, ме- } \\
\text { хан ізми оподаткування, методи оцінки об’єктів оподаткування тощо; }\end{array}$ \\
\hline & $\begin{array}{l}\text { валютна: національна валютна система та інфраструктура валютного рин- } \\
\text { ку, валютне законодавство і регулювання, валютно-курсова політика тощо; }\end{array}$ \\
\hline \multirow{4}{*}{ Організаційні } & $\begin{array}{l}\text { фінансово-кредитна: модель грошової емісії, механ ізми, методи та інстру- } \\
\text { менти регулювання, нагляду та контролю, система рефінансування та кап і- } \\
\text { талізації, захист капіталів, модель кредитування, методи оцінки кредито- } \\
\text { спроможності позичальників, ризик-менеджмент тощо; }\end{array}$ \\
\hline & $\begin{array}{l}\text { бюджетна: процедури бюджетного процесу, бюджетне планування і конт- } \\
\text { роль, бюджетна (платіжна) дисципліна тощо; }\end{array}$ \\
\hline & $\begin{array}{l}\text { nодаткова: фінансова дисципліна, методи податкового контролю, структу- } \\
\text { ра фіскального контролю, захист прав власності тощо; }\end{array}$ \\
\hline & $\begin{array}{l}\text { валютна: валютна стратегія, характер і моделі валютно-курсової політи ки, } \\
\text { валютний контроль і стабілізаційні механ ізми, управління валютним ризи- } \\
\text { ком тощо. }\end{array}$ \\
\hline
\end{tabular}

Джерело: розвинуто автором на підставі опрацювання $[12,19]$

Відповідно до визначених чинників спробуємо розкрити особливість їх прояву в умовах цифрової економіки через якісні характеристики цифрових технологій і фінансових інновацій на їх основі щодо очікувань і впливів на фінансову безпеку.

Фінансово-кредитна безпека. Найбільш радикальною фінансовою інновацією на основі цифрових технологій 
$\epsilon$ криптовалюта. Від своєї появи перелік її різновидів постійно зростає та вже становить більше двох тисяч, що свідчить про затребуваність серед інших криптоактивів, виникненню яких вона сприяла [18]. На наш погляд, сутнісна природа криптовалюти має значний потенціал i поліаспектний вплив на цифровізацію всіх економічних процесів і фінансову безпеку в тому числі, завдяки базовій технології блокчейн.

Перш за все треба відмітити, що питання здатності криптовалюти виконувати функції грошей залишається предметом багатьох теоретикометодологічних дискусій [20]. Натомість ділова практика надає нові підтвердження іiї активного використання.

Так, швейцарські банки Maerki Baumann та Incore Bank нещодавно отримали дозвіл від регулятора фінансового ринку FINMA на збереження, генерування (токенізацію) та запуск платформи для торгівлі цифровими активами (BTC, BCH, LTC і XRP), що дозволить банкам розширити спектр послуг 3 другого півріччя 2020 р. [21]. Центробанк Литви приєднався до світової тенденції вивчення цифрових валют, які здатні істотно вплинути на фінансову систему, і враховують ряд ïx переваг щодо забезпечення населення грошима у віддалених регіонах 3 обмеженим доступом до банкоматів та зменшення витрат для громадян, які працюють за кордоном і здійснюють грошові перекази. Також, центробанк у червні 2020 р. анонсував випуск власної колекційної цифрової монети на блокчейні NEM. У платіжний сервіс Samsung Pay, на частку якого припадає 80\% південнокорейського ринку платежів, планується додати можливість підтримки криптовалюти. Відпо- відно до Меморандуму щодо просування глобальних проектів протидії зміні клімату передбачено виплати компенсацій і винагород за зниження викидів парникових газів у криптовалюті. Тобто, маємо також багато інших свідчень використання криптовалют як платіжного засобу, заощадження та нагромадження, здатності ними виконувати також інші функції.

Позиція регуляторів країн світу до криптовалют не $є$ однозначною. 3 одного боку, вони усвідомлюють факт їх глобального поширення, розуміють необхідність прийняття чіткої позиції регулювання, а 3 іншого - займають позицію очікування. Жорстка позиція регуляторів не без підставна, адже маємо достатньо прикладів нелегітимного використання криптовалют для нелегальних транзакцій, торгівлі наркотиками, зброєю та іншими забороненими товарами [22, с.80]. Регулятори вводять обмеження і прагнуть мінімізувати ризики, які здатні вплинути на фінансову безпеку: 1) проникнення на внутрішні ринки іноземних фінансових установ як наслідок підвищення конкуренції та втрата ринкових позицій національними фінансовими установами; 2) втрати державної монополії на гроші; 3) зменшення сеньйоражу центральних банків; 4) зменшення попиту на національну валюту, що зумовлює іiі знецінення (а може навіть відмову на користь іноземної) та зміну швидкості обороту, що, у свою чергу, ускладнює процес визначення швидкості обігу грошей i проведення грошовокредитного регулювання; 5) неможливість проведення ефективної грошовокредитної політики, оскільки вагома частина грошової маси буде перебувати поза контролем; 6) зменшення рів- 
ня впливу або усунення фінансових посередників тощо [20, с.67-68].

Сьогодні криптовалюти суттєво не впливають на реальну економіку, грошово-кредитну політику, функціонування фінансової інфраструктури та фінансову стабільність, а ризики обмежені та керовані. Така ситуація пояснюється тим, що криптовалюти достатньо волатильні, процес їх поширення, як паралельної приватної валюти, відповідає теорії приватних грошей Ф. Хайека та теорії дифузії інновацій Е. Роджерса, а зростаюча динаміка цього процесу поки ще не досягла мотивованого максимуму прийняття більшістю, після чого криптовалюти можуть набути статусу офіційних грошей, а потенційні загрози стануть реальністю.

Так, ризики для монетарної політики можуть бути пов'язані зі зростанням капіталізації ринку криптовалют. По-перше, внаслідок збільшення криптовалютних операції на товарному ринку, відпливу капіталу за кордон цілком ймовірним $є$ очікування падіння попиту на національну валюту, що, в свою чергу, підвищить обсяг не залученої грошової маси до обслуговування товарообігу. Це матиме вплив на швидкість обігу грошей, грошові агрегати та їх оцінку, що ускладнить забезпечення цінової стабільності та очікуваного рівня інфляції. По-друге, за тих же обставин зазнає впливу процентна політика центрального банку. По-трете, враховуючи волатильність курсу криптовалют і залучення банків до криптовалютних обмінних операцій, зростатиме валютний ризик, наслідком чого стане втрата банками дохідності. Вразливими до валютного ризику банки також стають, якщо самостійно здійснюють операції $з$ крип- товалютами. Крім того, зростає кредитний ризик, якщо криптовалюта купується через кредитні картки. Почетверте, на значні ризики і втрати банки наражаються через кіберризики. По-П'яте, певні ризики створює невизначеність та/або зміна позиції центрального банку з ліберального до більш жорсткого регулювання та прямої заборони майнінгу, торгових операцій тощо.

Така ситуація склалась в Індії, де в 2018 р. Резервний банк Індії (RBI) прийняв постанову про заборону криптовалюти, який в 2019 р. підтримала урядова група 3 визначенням штрафних санкцій (3,5 млн дол США) та кримінальної відповідальності за його порушення (10 років позбавлення волі), проте це не стосувалось випуску цифрових токенів центральним банком. У березні 2020 р. Верховний суд Індії відмінив постанову RBI. Безумовно, ця ситуація позначилось на криптоіндустрії країни, коли внаслідок заборони закрились криптовалютні біржи і стартапи перемістились закордон, а країна втратила 13 млрд дол США. Скасування заборони вже за короткий час дало можливість зрости торговим обсягам, наприклад, біржи CoinDCX на 47\% і активних користувачів - на 150\%. Зараз RBI не забороняє банкам та іншим фінансовим посередникам обслуговувати криптовалютні установи.

Незважаючи ні на що, банки вважають, що потенційні можливості значно перевищують ризики. Наприклад, на початку 2020 р. банки СС отримали можливість надання послуг відносно криптовалют за умови дотримання вимог FATF. Цим дозволом передбачають скористатись майже 40 банків Німеччини, де в 2013 р. крип- 
товалюта була визнана фінансовим інструментом зі статусом «приватних грошей» при здійсненні клірингових операцій, а в 2018 р. - платіжним засобом.

3 огляду на це та необхідність врахувати сучасні технологічні тренди центробанки багатьох країн світу (ЄС, США, Японія, Китай, Канада, Швеція, Норвегія, Турція, ОАЄ, Україна, Уругвай, Венесуела та ін., загалом майже 70\% центральних банків) розпочали проекти щодо створення цифрових валют центральних банків (central bank-issued digital currency, CBDC). Поряд з означеним вище важливі також інші мотиви прийняття такого рішення. Для різних країн вони відрізняються, зокрема, це може бути прагнення подолати гіперінфляцію, повернути довіру до національних валют, здійснити повний перехід на безготівкові розрахунки і таким чином скоротити витрати на виготовлення і контроль готівкових коштів, зменшити тіньовий сектор, захистити податкову систему від офшоризації і протистояти відмиванню «брудних» коштів i фінансуванню тероризму. Передбачається, що CBDC буде побудовано на основі технології блокчейн, а відтак, їі можна вважати новим різновидом криптовалюти, емітентом якої $\epsilon$ центральний банк. Це дозволить йому доповнити (розширити) форму фіатної валюти, таким чином підтримати довіру до паперових грошей, підвищити ефективність, контроль, прозорість, безпеку і стабільності, зміцнити власні позиції та мінімізувати ризики, означені вище, в умовах цифрової економіки. В цьому контексті пророчим можна вважати вислів I. Мерша: «такі інноваційні технології, як блокчейн, здатні змінити традиційну глобальну фінансову екосистему. ...потенціал технології блокчейна можна використати як засіб для подальших інновацій центральних банків Свропи» [23]. Зауважимо, що проблематика CBDC не $\epsilon$ предметом статті і потребує окремих системних досліджень.

За відсутності централізованого нормативного регулювання позиція спостереження та очікувальна все більш схиляє регуляторів до створення регуляторних «пісочниць», а також взаємодії та підтримки саморегулівних організацій. В цьому аспекті корисним $€$ досвід ринку Південно-Східної Азії - інкубатору і випробувального майданчику для цифрової економіки. Так, Агентство фінансових послуг (FSA) делегувало частину своїх повноважень Асоціації ліцензованих японських кріптобірж (JVCEA), таким чином надавши кріптобіржам повноваження саморегулювання і створення технологій безпеки, боротьби з відмиванням коштів та нормативного регулюванням галузі [24].

Питання стосовно впливу криптовалюти на фінансову стабільність також $\epsilon$ невизначеним і відкритим до дискуcii $[9,25]$.

Щодо інституційних та організаційних аспектів забезпечення фінансової безпеки у фінансово-кредитній сфері необхідно чітке розуміння впливу фінансових інновацій на основі цифрових технологій на зміну інституційної структури фінансової та банківської систем, фінансового ринку. Останнім часом інституційна інфраструктура розширилась за рахунок появи, поряд 3 традиційними учасниками, високотехнологічних FinTech-компаній, кріптобірж, цифрових платформ тощо. Водночас бачимо скорочення мережі регіональних представництв як 
центральних, так і комерційних банків завдяки переходу на принцип «24/7/365» обслуговування споживачів за рахунок доступності і швидкості інтернету. Спостерігаємо трансформацію фінансового посередництва внаслідок поширення процесів цифровізації, посилення конкуренції та дезінтермедіації 3 боку FinTech-компаній [26]. Важливим є врахування появи, поряд 3 традиційним для фінансової безпеки операційним, кредитним, правовим ризиками, нових, зокрема, кібер-ризиків, що у відповідь вимагає побудови системи організаційних заходів ефективної протидії.

Валютна безпека. Еволюційний розвиток міжнародної валютної системи (MBC) завжди пов'язаний 3 глобальними подіями. Зокрема, в XXI столітті такими $є$ технологічний прорив, а також 3 кризовими явищами - фінансова криза 2008-2009 pp. i пандемія COVID19, свідками яких ми є сьогодні і які надали поштовх до формування цифрової фінансової системи і знов загострили проблеми традиційної міжнародної валютної системи (невідповідність стану міжнародного реального сектору економіки, нестабільність, необгрунтованість переваги долару, надмірне накопичення інвалютних резервів тощо). Деякі аспекти реформування МBC в умовах формування нової фінансової архітектури розкрито в роботі [27]. Ризики традиційної МВС під впливом криптовалюти варто очікувати на рівні радикальної зміни концепції грошей і нівелювання необхідності обігу традиційних грошей, трансформації міжнародних валютно-фінансових відносин та «дедоларізації» світових валютних ринків, посилення дезінтермедіації на валютних ринках i тиску на більшість традиційних фінансових посередників, міжнародне кредитування та залучення інвестицій.

Як аргумент наведемо думку М. Корні, керуючого Банку Великобританії, який пропонує створення мережи національних цифрових валют для формування і підтримки «синтетичної гегемонічної валюти» (SHC), обгрунтовуючи доречність національних і глобальної криптовалют існуванням «небезпечних дисбалансів, викликаних залежністю діючої системи від долара як світової резервної валюти» і необхідністю стабілізації міжнародної фінансової системи, виснаженої торговими і валютними війнами [28]. Зауважимо, що Банк Великобританіï першим розробив централізовану криптовалюту RSCoin, використовуючи переваги технології блокчейн [29].

Реагуючи на означені та інші дисбаланси, необхідність прийняття криптовалюти на системному рівні розуміють не тільки центральні банки, а також високотехнологічні FinTechкомпанії. Цілком закономірно, що урядом США це сприймається як загроза національній безпеці i втрати доларом статусу міжнародної резервної валюти. Тому, активний тиск і реакція протидії з його боку не заставила себе чекати у відповідь на заяву Facebook про впровадження криптовалюти Libra. Така ж реакція була по відношенню до Telegram, а саме заборона випуску криптовалюти Gram i зупинення ICO, коли вже було залучено 1,7 млрд дол США. На ці події також відреагувала Німеччина, затвердивши національну блокчейнстратегію, наголошуючи, що випуск валюти - це елемент суверенітету держави. Отже, країни світу отримали сигнал, що криптовалюти цілком зда- 
тні стати альтернативою національній валюті. Для традиційної МВС виник ризик трансформації кошику глобальних резервних валют внаслідок випуску приватних грошей та суверенних криптовалют центральних банків (CBDC), що не виключає усунення потреби в будь якій глобальній резервній валюті.

Також можна очікувати зміни на рівні міжнародних розрахунків, на інфраструктуру яких спирається традиційна фінансова екосистема, де значна роль належить міжнародній міжбанківській системі розрахунків SWIFT. Натомість, вже маємо приклад зміни банком Bank Frick (Ліхтенштейн) системи SWIFT на USDC на основі стейблкоінів - різновидності криптовалюти, яка має стабільне забезпечення (криптовалюта прив' язана до долару США у співвідношенні 1:1). Bank Frick став одним 3 провідних європейських блокчейн-банків, пропонуючи криптовалюту і кастодіальні послуги для інституціональних клієнтів і майнерів, набувши можливість прискорити обробку платежів [30].

Інший ризик для валютних ринків, пов’ язаний 3 криптовалютою, стосується міжнародного кредитування та залучення інвестицій, механізми яких трансформуватимуться внаслідок все більшого поширення технологій краундфандінгу та $\mathrm{ICO}$, які дозволяють залучати значні фінансові ресурси. В цьому напрямі показовими $є$ підходи Мальти щодо створення інфраструктури, визначення нормативного режиму і правил регулювання віртуальних фінансових активів, проведення ICO і залучення інвестицій [31]. Високо оцінюється законодавча ініціатива Республіки Білорусь щодо розвитку цифрової економіки та Парку високих технологій, в рамках якої визначено правила проведення ICO, створення i проведення торгів на криптобіржах, операцій $з$ криптовалютами та їх контролю тощо [32].

Бюджетна безпека. Рівень забезпечення бюджетної безпеки і стабільність бюджетної системи визначають фінансовий суверенітет країни, що вкрай важливо в умовах зростання зовнішніх загроз і внутрішніх дисбаланciB.

Недосконалість бюджетної політики та бюджетного механізму знаходить відображення в бюджетних відносинах, предметом яких є фінансові ресурси держави, їх мобілізація та розподіл, що, в свою чергу, призводить поряд 3 іншими чинниками до ризиків $\mathrm{i}$ загроз бюджетної безпеки. Сьогодні викликом для бюджетної безпеки стало використання криптовалюти та цифрових технології для цілей тіньової економіки та економіки терору, об'єктами яких є економічне зростання, прямі іноземні інвестиціі, фінансові ринки, торгівля, туризм та інші сфери, через нові моделі формування i руху нелегітимних фінансових потоків, конвертацію фіатних грошей в цифрові активи, незаконний вивід капіталу і нівелювання всіх заходів боротьби з боку державних органів і міжнародних організацій [33].

Внаслідок того, що криптовалюта поки ще не набула чіткого правового статусу і як платіжний засіб використовується поза традиційними фінансовими каналами, вона не підпадає під контроль грошових потоків і оподаткування, а, відтак, зменшується база оподаткування і бюджет не отримує повною мірою податкових надходжень, обсяг яких може бути достатньо значним, враховуючи капіталіза- 
цію ринку криптовалют, що посилює його розбалансованість. Інвестиції в криптовалюту 3 метою отримання надприбутку завдяки іï високого курсу, незважаючи на ризики, призведе до зменшення заощаджень у традиційній формі та ресурсної бази фінансових посередників, як наслідок, спостерігатиме обмеження можливостей традиційного механізму трансформації заощаджень в інвестиції. Збільшення обігу криптовалюти в бізнеспроцесах зменшить попит на національну валюту, а можливість отримання фінансових ресурсів на платформах краудфандінгу - на депозитні, розрахунково-касові і кредитні послуги фінансових посередників 3 втратою ними дохідності. Водночас, скоротяться надходження до бюджету від таких внутрішніх джерел як доходи центральних банків, які формуються за рахунок сеньйоражу та операційного доходу, що обмежить можливості кредитування уряду і негативно позначиться на обслуговуванні зовнішнього боргу та фінансовій безпеки країни.

Відповідно до цього, поряд 3 традиційними підходами стратегіi забезпечення бюджетної безпеки повинні враховувати тенденції, нові виклики та загрози, які привносить поширення процесів цифровізації, щодо збалансованості і кореляції між бюджетною стратегією, системою та бюджетами

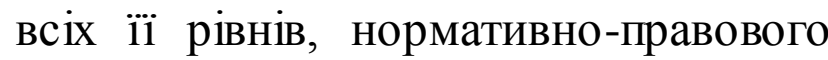
забезпечення, інструментів бюджетного регулювання та підвищення їх ефективності, довгострокової політики заощаджень i інвестицій, податкової дисципліни тощо.

Податкова безпека. Якщо розглядати криптовалюту 3 точки зору податкової безпеки як складової фінансової безпеки, то зазначимо, що вона, за ра- хунок таких властивостей як анонімність, конфіденційність, швидкість, транскордонність і мобільність транзакцій, сприяє зростанню ухилень від сплати податків, стає аналогом офшорів, розмиває базу оподаткування. У відповідь на такий виклик новою практикою стало, наприклад, об'єднання зусиль податкових органів США, Австраліі, Великобританіі, Канади і Нідерландів щодо розслідування схем ухилення від сплати податків 3 використанням криптовалюти. Також на сьогодні вже можна стверджувати про напрацювання підходів до оподаткування криптовалюти, що безпосередньо пов'язано 3 однозначним визначенням іiі правового статусу. На практиці активно впроваджується оподаткування для майнерів, криптоінвесторів криптовалютних бірж, споживачів криптоактивів (США, Німеччина, Канада, Індія, Сінгапур, Південна Корея, Киргизстан та ін.). 3 точки зору стратегічних цілей забезпечення фінансової безпеки в країнах світу створюються умови для подальшого стабільного розвитку, а тактичні враховують необхідність забезпечення податкової безпеки та однозначно визначають правовий статус криптовалюти, політику та режими оподаткування, оцінки ризиків та підходів їх нейтралізації [34]. Щодо нівелювання можливості формування загроз податкової безпеки значної уваги потребують інституційні та організаційні чинники. Зокрема, потрібно проводити трансформацію національних податкових систем і податкового законодавства, напрацьовувати нові підходи здійснення податкового контролю i підвищення фінансової дисципліни в умовах цифрової економіки. 
Потенційні можливості ичирових технологій забезпечити фінансову безпеку. Аналізуючи сутність і можливості інших цифрових технологій (Big Data, штучний інтелект, машинне навчання, блокчейн) і фінансових інновацій на їх основі, зазначимо, що вони мають більш виражений позитивний потенціал для створення інструментів нейтралізації загроз фінансової безпеки.

На думку експертів, монетарна політика розвинених країн світу наближається до межі своєї ефективності [35], що вказує на потребу нових підходів, спираючись на нові джерела неструктурованих даних - соціальні мережи, традиційні інформаційні системи, інтернет речей. Так, технологія Big Data дозволяє в реальному часі відслідковувати стан економіки і вимірювати інфляцію за визначеним спектром індикаторів, спираючись, наприклад, на ціни в он-лайн магазинах, динаміку ринку праці, нерухомості, ділові очікування тощо), що підвищує якість аналізу і прогнозування, створює можливість завчасно виявляти проблеми i надає грошовокредитній політиці більшої гнучкості та стійкості. Корисною технологія Big Data може бути при управлінні валютними резервами та визначені оптимального їх обсягу, прогнозуванні валютних ризиків і забезпеченні стійкості національної валюти. Щодо проденційної політики, то від використання Big Data ефекти варто очікувати при забезпеченні фінансової стабільності, стрес-тестуванні, боротьбі з відмиванням коштів і фінансування тероризму, розкритті шахрайських схем тощо. На рівні фінансового посередника технологія Big Data важлива для визначення платоспроможності клієнта, виявлення основних каналів транзакцій, сегментації та персоніфікації пропозиції продуктів і послуг, управління фінансовими ресурсами і кредитною заборгованістю, оцінки ризиків і антикризового управління, виконання вимог регулятора та подання звітності тощо. Тобто, такі підходи є якісним доповненням до традиційних, надаючи оперативно повну та деталізовану інформацію покращують операційну ефективність, забезпечення фінансової стабільності і фінансово-кредитної безпеки.

Поряд 3 цим, значні обсяги даних потребують сучасних методів, до яких належать технології штучного інтелекту (AI) та машинного навчання (Machine learning, ML), що дозволяють перетворити їх на знання. Серед напрямів використання AI i ML центральними банками варто відмітити: 1) удосконалення прогнозного та аналітичного інструментарію; 2) дослідження ринку щодо транспарентності центрального банку та поведінкових трендів; 3)управління активами - виявлення динаміки змін курсу валют i цін на цінні папери, дорогоцінні метали для вироблення моделей торгівлі, відстеження реакції ринку на процентні ставки центрального банку; 4) аналіз ринку - виявлення змін цін активів для побудови стратегій їх розподілу, забезпечуючи баланс між ризиками і дохідністю; 5) управління державними цінними паперами - виявлення динаміки змін для вироблення моделей торгівлі; 6) управління ризиками оцінка фінансової стабільності; 7) підтримка користувачів за допомогою чат-ботів; тощо. Для комерційних банків та інших учасників ринку важливим є вірне розуміння висловлювань центральних банків як сигналів їх 
майбутньої політики. В цьому напрямі дослідницький центр Nordea Research на основі AI в 2019 р. розробив інструмент Hawk-o-Meter для прогнозування грошово-кредитної політики ФРС, СЦБ, Банку Великобританіі, Швеції щодо підвищення/зниження процентних ставок. Результати такого прогнозу публікуються в Twitter та Bloomberg. Поширення AI та ML в комерційних банках пов'язано з вирішенням проблем управління фінансовими, операційними і кредитними ризиками, а також для автоматизації служб підтримки за допомогою Чатботів для підвищення якості обслуговування і захисту від репутаційних ризиків за рахунок скорочення часу очікування і збільшення кількості оброблених запитів, постійного самонавчання на основі ML. Це дозволяє підвищити продуктивність i зменшити витрати важливих ресурсів, які в подальшому спрямовуватимуться на створення нової цінності.

Стосовно потенціалу використання цифрових технологій (Big Data, AI, ML, блокчейн, інтернет речей) в сфері управління державними фінансами $\mathrm{i}$ підвищення бюджетної безпеки зауважимо, що такі технології стануть дієвим інструментом макроекономічного i бюджетного прогнозування, планування та аналізу виконання бюджету, оцінки впливу проектів нормативно-правових і законодавчих актів на бюджет, ведення державних реєстрів, управління активами держави та державними інвестиціями, вдосконалення системи електронних закупівель тощо [36]. Все це в цілому зменшить ризики бюджетної безпеки.

Прикладом використання цифрових технологій в сфері оподаткування може слугувати проект AI Economist компаніï Salesforce, що здійснюе імітаційне моделювання ідеальної податкової системи, до побудови якої прагнуть всі країни світу. Також ці технології здатні підвищити ефективність адміністрування податкових надходжень і протидії зловживанням і порушенням, більш точно прогнозувати та розраховувати базу оподаткування, удосконалити внутрішній контроль i аудит оподаткування, розширити електронні сервіси для платників податків тощо.

Нівелювання ризиків фінансової безпеки сприяють також технологія RegTech для підвищення ефективності виконання вимог регулятора та SupTech для забезпечення ефективних способів виявлення та оцінки ризиків, збору та аналізу даних.

Висновки. Цифрова економіка, процеси цифровізації та впровадження фінансових інновацій на основі цифрових технологій $\epsilon$ незворотнім процесом еволюційного розвитку. В умовах цифрової економіки і зростання значущості інформаційних і технологічних факторів для економічного розвитку трансформується система загроз. Водночас змінюється специфіка впливів на фінансову безпеку та окремі її структурні складові, попередження руйнівної дії яких потребує розробки та реалізації практичних заходів удосконалення механізмів іiі забезпечення. Трансформаційні зміни ділового економічного середовища призводять до необхідності динамічного відгуку на цифрові тренди, формування спроможності впровадження фінансових інновації на основі цифрових технологій, моніторингу фінансової безпеки для оцінювання захищеності, стабільності та стійкості фінансової системи, достатності економічного 
потенціалу для ринкової та соціальної

інклюзії.

\section{Список використаної літератури}

1. Винья П. Эпоха криптовалют. Как биткоин и блокчейн меняют мировой экономический порядок. М.: ООО «Манн, Иванов и Фербер», 2017. 580 с.

2. Vovchenko N., Tishchenko E., Epifanova T., Gontmacher M. Electronic Currency: The Potential Risks to National Security and Methods to Minimize Them. European Research Studies Journal, 2017. vol. XX, issue 1, 36-48.

3. Gomber P., Koch J.-A., Siering M. Digital finance and FinTech: Current research and future research directions. Journal of Business Economics. 2017. Vol. 87(5). P. 537-580. DOI: 10.1007/s11573-017-0852-x.

4. Darolles S. The rise of fintechs and their regulation. Financial Stability Review, 2016, issue 20, pp. 85-92.

5. MacDonald T., Allen D., Potts J. Blockchains and the Boundaries of SelfOrganized Economies: Predictions for the Future of Banking. URL: https://papers.ssrn.com/sol3/papers.cfm?abstract_id=2749514 (дата звернення 12.04. 2020).

6. Malone M.S. The Big-Data Future Has Arrived. URL: https://www.wsj.com/artic les/the-big-data-future-has-arrived-1456184869. (дата звернення 12.04. 2020).

7. Карчева Г.Т. Віртуальні інноваційні валюти як валюти майбутнього. $\Phi i-$ нансовий простір. 2015. № 2 (18). С.23-29.

8. Корнєєв В., Чеберяко О Криптовалюти: ера і сфера фінансових інновацій. Вісник Київського національного університету імені Тараса Шевченка. 2018. № 1(196). C.40-46.

9. Pantielieieva N., Khutorna M., Lytvynenko O., Potapenko L. FinTech, RegTech and Traditional Financial Inter-mediation: Trends and Threats for Financial Stability. Data-Centric Business and Applications: Evolvements in Business Information Processing and Management. Springer, 2019, Vol. 3, pp. 1-21. https://doi.org/10.1007/978-3-030-35649-1

10. Treleaven P. Financial regulation of FinTech, Journal of Financial Perspectives, 2015, vol. 3, issue 3, pp.114-121. 
11. Omarini A. The Digital Transformation in Banking and The Role of FinTechs in the New Financial Intermediation Scenario. URL: https://mpra.ub.unimuenchen.de/85228/1/MPRA_paper_85228.pdf. (дата звернення 12.04. 2020).

12. Барановський O.І. Філософія безпеки : монографія : у 2 т. Київ : УБС НБУ, 2014. Т. 1 : Основи економічної і фінансової безпеки економічних агентів. $831 \mathrm{c}$.

13. Клоков Е. А. Финансовая безопасность государства: сущность и современные угрозы URL: https://cyberleninka.ru/article/n/finansovaya-bezopasnostgosudarstva-suschnost-i-sovremennye-ugrozy (дата звернення 12.04.2020).

14. Єрмошенко М. М. Фінансова безпека. Віче. 1998. № 11. С. 61-73.

15. Бланк И. А. Управление финансовой безопасностью предприятия. К. : «Ника-Центр», 2002. 751 с.

16. Болгар Т. М. Фінансова безпека банків в умовах ринкової трансформації економіки України: автореф. дис. на здобуття наук. ступеня канд. екон. наук: спец. 08.00.08 / Т. М. Болгар. Суми: ДВНЗ «УАБС НБУ», 2009. 22 с.

17. Вовк В. Я. Теоретические основы обеспечения финансовой безопасности. Проблеми економіки. № 4. 2012. С. 200-204.

18. Pantielieieva N. M., Rogova N. V., Braichenko S. M., Dzholos S. V., Kolisnyk A. S. Current aspects of transformation of economic relations: cryptocurrencies and their legal regulation. Financial and credit activity: problems of theory and practice, Vol 4, No 31 (2019), 410-418. DOI: https://doi.org/10.18371/fcaptp.v4i31.190962 19. Громова А.С., Воробьева И.П. Источники опасностей и основные угрозы экономической безопасности бюджетной политики URL: https://core.ac.uk/download/pdf/53067617.pdf (дата звернення 12.04. 2020). 20. Пантєлєєва, Н. М. Нові форми грошей в умовах формування інформаційного суспільства. Вісник НБУ. 2015. № 5 (травень). С. 25-31.

21. Два швейцарских банка получили одобрение FINMA на предоставление криптоуслуг. URL: https://bitnewstoday.ru/news/dva-shveytsarskikh-bankapoluchili-odobrenie-finma-na-predostavlenie-kriptouslug/ (дата звернення 12.04. 2020).

22. Отчёт о взаимной оценке. Меры по противодействию отмыванию денег и финансированию терроризма Российская Федерация. 2019. URL: https://www.fatf-gafi.org/media/fatf/documents/reports/mer4/fatf-2019rossijskaa-federacia.pdf (дата звернення 12.04. 2020). 
23. Банк Японии и ЕЦБ тестируют возможности блокчейна.

URL: https://bits.media/news/bank-yaponii-i-etsb-testiruyut-vozmozhnostiblokcheyna/ (дата звернення 12.04. 2020).

24. Как азиатское саморегулирование изменит будущее цифровой экономики URL: https://bitnewstoday.ru/news/kak-aziatskoe-samoregulirovanie-izmenitbudushchee-tsifrovoy-ekonomiki/ (дата звернення 12.04. 2020).

25. Crypto-Assets: Implications for financial stability, monetary policy, and payments and market infrastructures. URL: https://www.ecb.europa.eu/pub/pdf/ scpops/ecb.op223 3ce14e986c.en.pdf (дата звернення 12.04. 2020).

26. Pantielieieva N., Zaporozhets S., Nagaichuk N., Bartosh O. Transformation of financial intermediation in the context of spread of digital trends. BULLETIN OF THE NATIONAL ACADEMY OF SCIENCES OF THE REPUBLIC OF KAZAKHSTAN, 2019. № 3. pp. 144-152. DOI: https://doi.org/ 10.32014/2019.25181467.80)

27. Пантєлєєва Н.М. Реформування міжнародної валютної системи в умовах формування нової фінансової архітектури. Фінансовий простір. 2011. № 3. C. $28-42$.

28. Синтетическая валюта гегемона: управляющий Банка Англии Марк Карни предлагает глобальную цифровую валюту URL: https://ru.0xzx.com/201908273 1143.html (дата звернення 12.04. 2020).

29. The Bank of England creates own digital currency not entirely unlike Bitcoin URL: https://www.firmex.com/resources/blog/bank-of-england-blockchain-digitalcurrency-bitcoin/ (дата звернення 12.04. 2020).

30. Европейский банк использует стейблкоины вместо SWIFT URL: https://bitnewstoday.ru/news/evropeyskiy-bank-ispolzuet-steyblkoiny-vmestoswift/ (дата звернення 22.04. 2020).

31. Юрисдикция Мальты - одно из лучших мест для запуска ICO и развития криптобизнеса URL: https://internationalwealth.info/cryptocurrency/malta-one-ofthe-best-places-for-launching-ico-and-developing-crypto/ (дата звернення 22.04.2020).

32. Декрет № 8 «О развитии цифровой экономики» URL: https://www.belrynok.by/2017/12/23/dekret-8-o-tsifrovoj-ekonomike-polnyjtekst/ (дата звернення 22.04. 2020). 
33. Pantielieieva N., Revera E. The multifaceted nature of the impact of digital technology on the economy of terror. Financial Space. 2019. № 4(36). P. 204-212. DOI: https://doi.org/10.18371/fp.4(36).2019.190235

34. Рогова Н.В. Проблемні аспекти оподаткування криптовалют. Розвиток банківських систем світу в умовах глобалізації фінансових ринків : Матеріали XIII Міжнародної науково-практичної конференції. 25 жовтня 2019 р. Черкаси: ЧННІ ДВНЗ «Університет банківської справи», 2019. С. 43-46.

35. Panizza, U., Wyplosz, C. The Folk Theorem of Decreasing Effectiveness of Monetary Policy: What Do the Data Say? Russian Joumal of Money and Finance, 2018, 77(1), pp. 71-107. DOI: https://doi.org/10.31477/rjmf.201801.71 (дата звернення 22.04. 2020).

36. Пантєлєєва Н.М. Інноваційна технологія блокчейн у системі управління державними фінансами. Науковий вісник Ужсгородського університету. Серія «Економіка», 2018. Випуск 1 (51). C. 363-369. DOI: https://doi.org/10.24144/24096857.2018.1(51).363-369 